\title{
Carta de la decana
}

\section{Marien Yolanda Correa Corredor*}

$\mathrm{L}$ a Revista DIXI, publicación de la Facultad de Derecho de la Universidad Cooperativa de Colombia, sede Bucaramanga - documento valioso que acoge el resultado de investigaciones emanadas de diferentes personas de la comunidad académica universitaria, constituida por profesores, investigadores y estudiantes, así como los productos teóricos realizados en otras latitudes- llega a su Volumen 15, Número 17, con la confluencia de artículos de altísima calidad científica local e internacional.

Es por ello que con satisfacción se comparte la aglutinación de temas, eso sí, sin abandonar las líneas de investigación de nuestra Facultad de Derecho, para comparar, desde una perspectiva de construcción positiva, aquello que se erige internamente y el trabajo de autores extranjeros. Este ejercicio nos ha permitido entender que el proceso de producción académica debe ser hacia afuera, con el fin de que la comunidad académica internacional conozca nuestra producción investigativa. Pero también, y en aras de formar redes alrededor de temas de interés sociojurídico, continuamos con espacios para autores extranjeros. Precisamente, en esta edición participa el maestro español Sebastián Félix Utrera Caro, con su artículo "Agua, trasvases y medio ambiente. Los aspectos ambientales de los trasvases", escrito que, como su autor lo indica, se enmarca dentro de un proyecto de investigación sobre la gestión del agua por cuencas fluviales y por Estados, regiones o comunidades autónomas, apoyado por la Universidad CEUSan Pablo en Madrid, España y por el Banco Santander. De igual manera, se agrega el artículo "Exploração sexual da criança e do adolescente no Brasil", cuyas escritoras son las profesoras brasileñas Grasiele Augusta Ferreira Nascimento y Maria Aparecida Alkimin, quienes pertenecen al Centro Universitario Salesiano de São Paulo (UNISAL) en Brasil como miembros del grupo de investigación "Minorías, discriminación y efectividad de los derechos".

Asimismo, y es importante resaltarlo, en este número se quiso valorar el ejercicio académico investigativo de estudiantes de la Facultad de Derecho, quienes no sólo cumplieron con su requisito de grado, sino que dejaron huella en diferentes escenarios comunitarios con sus investigaciones terminadas; algunos de ellos presentan sus artículos en forma conjunta con sus asesores temáticos o directores de trabajo. Nos referimos a los trabajos de Yenny Cristina Grass Suárez, Ximena Cristina García Caicedo, con el apoyo del profesor César Augusto Romero Molina, denominado "Principios constitucionales que rigen el sistema tributario"; al de Elda Yazmín Márquez y Javier Alfonso García Carvajal titulado "La circuncisión como una manifestación de vulneración al derecho al libre desarrollo de la personalidad"; al de Martha Isabel Pérez, Walter Guevara y José Adán Ariza García, titulado "Unión marital de hecho: análisis jurisprudencial del derecho a la igualdad para los compañeros permanentes"; al de An- 
gélica Johanna Rojas Cabeza y su profesor sobre el "Alcance y aplicación del concepto de gasto público social en el ordenamiento jurídico colombiano", y, finalmente, el del profesor César Augusto Romero Molina y las egresadas Ligia Colmenares Jácome y Andrea Catalina Murillo Olarte, llamado "Sistema y método para fijar las tarifas de tasas y las contribuciones”. La selección de los artículos de los estudiantes respondió al deseo de mostrar los frutos de la formación para la investigación con una diversidad de pensamientos, como condición necesaria en la formación con criterios políticos en nuestra Universidad. La intención, y así lo consideraron los comités científico y editorial de la Revista DIXI, fue aceptar el devenir reflexivo para conocer la creación de los discentes desde su pluralidad de pensamientos y bajo su inmutable fluir de ideas luego de terminar sus monografías de grado. Se concluye, entonces, que esta edición semestral sigue siendo constante con la calidad de nuestra revista.

Es así como desde la Decanatura de la Facultad de Derecho, expresamos a todos los autores colaboradores nuestro reconocimiento por haber hecho posible esta producción. A la postre, creemos que este número seguirá motivando a otros investigadores, y en especial a profesores y estudiantes de Bucaramanga y otras ciudades, para que mantengan una actitud intelectual permanente; para que fortalezcan su motivación en el ejercicio de la escritura y la lectura crítica; para que aporten el resultado de sus investigaciones, y, definitivamente, para que el ejercicio investigativo escrito con las voces de los jóvenes se mezcle con las palabras y los pensamientos de los mayores. 


\section{Letter from the Dean}

\section{Marien Yolanda Correa Corredor ${ }^{\star}$}

$\mathrm{T}$

The DIXI Journal, a publication by the Law Faculty at the Bucaramanga campus of the Universidad Cooperativa de Colombia, is a valuable document that contains the results of research by diverse professors, researchers and students from the university academic community, and also includes theoretical products from other countries. The current issue is volume 15, number 17, and consists of articles of the highest local and international scientific quality.

It is thus a source of satisfaction to be able to share these topics, without abandoning the research lines of our Law Faculty, in order to compare, from the perspective of positive construction, what is created internally as well as work by foreign authors. This has enabled us to understand that the process of academic production must be aimed outside the university so that the international academic community will become familiar with our research production. Also, to build networks around topics of socio-legal interest, we continue to provide a venue for foreign authors. This issue thus includes an article by the Spanish professor Sebastián Felix Utrera Caro, entitled "Water, Transfers and the Environment. The Environmental Aspects of Transfers". It is framed within a research project on water management by river basins and states, regions or autonomous communities, which is sponsored by the Universidad CEU-San Pablo in Madrid, Spain and the Banco Santander. This issue also includes an article entitled "Sexual Exploitation of Children and Adolescents in Brazil", by Brazilian professors Grasiele Augusta Ferreira Nascimento and Maria Aparecida Alkimin, who work at the Centro Universitario Salesiano de São Paulo (UNISAL) in Brazil as members of the research group on Minorities, Discrimination and Effectiveness of Rights.

It is also important to stress that this issue aims to highlight academic research by students from the Law Faculty, who not only have fulfilled their requirement for graduation but also left their mark on diverse community venues with their finished research work. Some present their articles jointly with their thematic advisors or research directors. We specifically refer to works by Yenny Cristina Grass Suárez and Ximena Cristina García Caicedo, with support from professor César Augusto Romero Molina, entitled "Constitutional Principles Governing the Tax System"; by Elda Yazmín Márquez and Javier Alfonso García Carvajal entitled "Circumcision as a Manifestation of Violation of the Right to Free Personality Development"; by Martha Isabel Pérez, Walter Guevara and José Adán Ariza García, entitled "De facto Marital Union: a Jurisprudential Analysis from the Perspective of the Right to Equality for Partners"; by Angélica Johanna Rojas Cabeza and her professor on the "Scope and Application of the Concept of Public Social Spending in the Colombian Legal System", and finally work by professor César Augusto Romero Molina and graduates Ligia Colmenares Jácome and Andrea Catalina Murillo Olarte, entitled "System and Method to Define the Cost of Tax and Contribution Rates". Students' articles were selected to show the results of training in research with a diversity of thinking, as a necessary condition for education 
with political criteria at our university. The intention, which was taken into account by the scientific and editorial committees of the DIXI Journal, was to accept the evolution of the authors' reflections so as to understand their creations based on their diverse thoughts and immutable flow of ideas after finishing their graduation papers. The conclusion, therefore, is that this edition remains consistent with the quality of our journal.

We at the Office of the Dean of the Law Faculty express our gratitude to those who have collaborated in this edition for having made it possible. At the same time, we believe this issue will continue to encourage other researchers, and particularly the professors and students of Bucaramanga and other cities, to maintain a permanent intellectual attitude; to strengthen their motivation to write and read critically; to contribute the results from their research; and so that research work written by young voices will mix with the words and thoughts of their elders.

\footnotetext{
Dean of the Faculty of Law Universidad Cooperativa de Colombia, Bucaramanga, Campus
} 